\title{
A Sinicized World Religion?: Chinese Christianity at the Contemporary Moment of Globalization
}

\author{
Nanlai Cao
}

School of Philosophy \& Institute of the Study of Buddhism and Religious Theory, Renmin University of China, 5/F Renwen Building, Beijing 100872,China; nanlai_c@hotmail.com

Received: 17 July 2019; Accepted: 30 July 2019; Published: 1 August 2019

\begin{abstract}
This essay explores the rise of Protestant Christianity at the contemporary stage of China's globalization as a unique social and cultural phenomenon. Globalization can be seen as not only a homogenization process in political and economic terms, but also a process in which religious ideas and moral principles spread around the world. While in an earlier phase of globalization lack of Christianity was once constructed as a moral argument to ban Chinese migration to the Christian West, in the current context of China's aggressive business outreach and mass emigration Christianity has become a vital social force and moral resource in binding Chinese merchants and traders in diaspora. By linking the rise of a sinicized version of Christianity in secular Europe with China's present-day business globalization, I hope to suggest a new transnational framework for studying Chinese Christianity, which has often been examined in the nation-based political context of church-state relations, and for rethinking it beyond the static, decontextualized system of world religions.
\end{abstract}

Keywords: Chinese Christianity; Chinese Diaspora; transnational religion; migrant entrepreneurship; globalization; Europe; Christian mission

\section{Introduction: The Nexus of Religion and Globalization}

The last two centuries have witnessed the intertwined development of religion and state secularism in the global context of nation-building. The rise of the modern category of "religion" itself was a global phenomenon accompanied by the formation of modern nation states worldwide (Asad 1993; van der Veer 2013). While at the contemporary moment globalization has often been understood in terms of the global spread of the ideologies and institutions of neoliberalism, consumerism, and migration, this is far from a homogenizing process as many social scientists have found out. On the contrary, there has been a dynamic return to the strong nation-state, the rise of the new state space, and local-place based identity. Globalization has sometimes contributed to the resilience of authoritarian states by channeling strategic resources from around the globe to build up state capacity to prevent democratic change, and it can also lead to the rise of transnational religious extremism and religiously inspired violence by promoting religion's entanglement with political power and ideology as evidenced by the tragic attacks of 11 September 2001. Along with the resurgence of world religions or the great traditional faiths, new religious movements, syncretic religious practices, and new immigrant religions have flourished which often reflect the meshing of local popular culture, folk spiritualties, nationalist sentiment, and institutional religious traditions in the global religious domain. To better understand the fate of religion in an increasingly globalized world, we need to take into account these new geopolitical configurations and power contestations and achieve a more contextualized understanding of lived religious experience. This paper explores the nexus of religion and globalization in a concrete Chinese social context from an empirically grounded bottom-up approach.

Previous studies show that Western religious ideas do not transform local Chinese conditions in a simple, uniformed fashion, but work in ways mediated by local structures and concepts, and local 
Chinese are not passive recipients of global forces, mostly of European and North American origin (Jansen et al. 2014). There exist diverse, multiple actors within the Chinese religious field. These actors and agents usually include the state, religions, academics, Western missionaries, and Chinese religious reformers and merchants. Their ideas and practices have interacted and played an important part in the transformation of the Chinese religious field over the last two centuries of drastic political and social change.

China's modernization can be seen as a globalizing project. Given the historical linkage between Christianity and Western institutions there is much congruence between categorizations rooted in western modernity and the self-understanding of societies and organizations dominated by Christian culture. As China began to be integrated into the modern world system, globally generalized concepts such as religion were being applied, challenged, and modified in the Chinese context, where there was incommensurability between taxonomies associated with Christianity and the reality constructed through traditional Chinese religious and cultural lens. Much of existing research highlights the importance of Christianity as the normative model of religion in the making of the Chinese religious field (see Goossaert and Palmer 2011). Not surprisingly, the interrelationship between religion and globalization has primarily been set in the historical context of the encounter between missionary figures and local Chinese agents, further reinforcing the dichotomous ordering of the western global and the Chinese local (see Cao 2018). While the China/West dichotomy appears visible in discussions of the role of Western Christian forces and concepts in shaping the Chinese religious scene, there is an intellectual urgency of challenging a seemingly common narrative of globalization that assumes it originated in the West and spreads to other parts of the world, thus transforming the lives of non-western local people. When people talk about religion and globalization, the concept of religion usually refers to Abrahamic religions and encompasses such abstract and seemingly universal notions as truthfulness, justice, and compassion (e.g., Volf 2016). This emphasis is deeply rooted in Protestant theology in the western context where western Christianity has become the prototype of global religion. Drawing on ethnographic field research conducted among Chinese Christians in Europe spanning over a decade, I hope to establish a framework for rethinking the contemporary link between Chinese Christianity and China's globalization so as to counter the Western-centric view on Christianity's one-way penetration of Chinese society and culture. ${ }^{1}$

Christianity has figured prominently in the history of China-West encounters. While stories and studies of western missionaries to China are plentiful and common, the neglected other side of the coin is the western opposition of Chinese immigrants based on perceived non-Christian compatibility. For example, in U.S. history there was a long period of time from 1882 to 1965 when Chinese immigration was strictly restricted by the federal Chinese Exclusion Act of 1882 and the national quota system (1943-1965). Although economic competition in the American west appeared to be the major motivation behind Chinese exclusion, lack of Christian values and allegiances on the part of the Chinese was a paramount concern among American policy-makers and factored strongly in the moral argument against Chinese immigration, especially the immigration of Chinese women because of "the widely held view that all Chinese women were prostitutes" (Chan 1991, p. 95). Much of the stereotypical knowledge about the Chinese being immoral "pagans" and "heathens" was evidently derived from early western Christian mission efforts in China, and partly a byproduct of racial distinction and white supremacy. Due to the exclusion-era law prohibiting the immigration of the wives or families of Chinese, there was an extremely skewed sex ratio among the Chinese in the U.S. during the first half of the twentieth century, and white missionary-led churches in the bachelor society of Chinatown served as important "rescue homes" for women facing the serious problems of concubinage and prostitution (Cayton and Lively 1955). Both in China and the Chinese diaspora early Western missionaries conceived

1 See DeBernardi (2001) and Nagata (2005) for pioneering studies on diasporic Chinese Christianity in postcolonial Southeast Asia, which presents an interesting reference point for understanding the role of Chinese agency in localizing and contextualizing the global religion. 
of their work to evangelize "heathens" in the "aggregated paganism", thus distancing themselves from the indigenous elements of the Chinese world.

Soon after the establishment of the People's Republic of China in 1949, foreign missionaries were expelled by the new Communist regime. Christianity has been thoroughly indigenized through close contact with immediate local Chinese realities. The influence upon Chinese Christianity directly brought by western missionaries has faded away but a lot comes from immigrant Chinese Christian churches overseas instead, exhibiting a mode of mutual penetration between the Chinese churches in China and those based in diaspora. Since the turn of the new century Europe has become increasingly the center of global migrations from other parts of the world. Chinese immigrants, such as those from Chinatowns in Paris and Rome, have formed transnational church networks that originate in China, and whose operations largely rely on ethnic trading communities and networks. Therefore, this is a story of multidirectional religious transmission under globalization, rather than an overwhelmingly unidirectional movement from the global center to the passive margin or the cultural penetration and reconstruction of Chinese society by the west that characterizes the early modern phase of globalization (see Casanova 2018). The following analysis puts emphasis on issues concerning Christianity and community formation among the Chinese diaspora in France and Italy, the organization and social impact of Chinese immigrant churches, and the development trajectory of Chinese Christianity in the contemporary post-modern, post-secular global age.

\section{Chinese Christianity in Diaspora: Beyond Cultural Assimilation}

So far, little scholarly attention has been paid to the globalization of Chinese Christianity or the story of Chinese Christianity on a global stage. Research on Chinese Christianity in diaspora has mainly focused on Chinese conversion to Christianity which is the majority religion in the Western context (see, e.g., Cao 2005; Yang 1999). However, we know little about how Chinese migrants brought with them their own homegrown Christian faith to the West and other parts of the world from China and created their religious diaspora and mission stations. ${ }^{2}$ The mass participation of Chinese merchants and traders in migrant churches in Europe contrasts sharply with the mass conversion of Chinese professionals (scholars and students) to Christianity in the United States (see Yang and Tamney 2006). The latter group has been well documented, while increasingly secularized Europe provides a new context for researching Chinese Christianity that cannot be seen simply in terms of a unidirectional mode of assimilation to a Western religious culture, but rather the antidote to assimilation.

Unlike in the United States, where religion in general and Christianity in particular enjoys privileged status in society, in highly secularized Europe, state regulatory framework generally discourages the active presence of immigrant religion in social life, and churchgoing is not considered a virtue by the public. ${ }^{3}$ However, as this study shows, a highly indigenized Chinese Christianity has taken roots in post-Christian Europe almost in total isolation from local European Christians and churches. In recent decades, a large number of Chinese Christians, originated from the coastal Chinese city of Wenzhou, have migrated to Europe especially France and Italy without proper travel documents and with a sole purpose to make money. ${ }^{4}$ Many of them were previously rural migrant entrepreneurs and itinerant traders within China before emigration ( $\mathrm{Li} 1999)$. According to various estimates by immigrant church insiders, there are hundreds of Chinese churches across Europe. Italy is home to around 70 Chinese churches and nearly 30,000 Chinese believers, constituting the largest presence of Chinese Christianity in Europe. France has the second largest Chinese church community in Europe, with around 40 Chinese churches and 10,000 church members, mostly concentrated in the urban districts of Paris. One important feature that distinguishes these Chinese Christians in Europe

\footnotetext{
See Cao (2013a) and Cao et al. (2018) for two notable exceptions.

See Berger et al. (2008) for a contrast between the religiosity of the United States and the secularity of Europe.

The issue of migrant illegality is generally downplayed in the church setting. When asked, they often invoke the notion of God's grace to provide moral legitimacy for their theoretically illegal migration and business practices.
} 
from those in North America is that they are mostly not new converts but had become Christians in China before emigration.

Since the turn of the new century, the large group of Chinese migrant traders and merchants from the Wenzhou region has acquired great visibility and begun to dominate the Chinese churches in Europe. ${ }^{5}$ The Chinese communities in Europe are heterogeneous in terms of their geographic origins, their migratory patterns and the multiplicity of the waves of their migration. However, it seems that only these Wenzhou people have been able to build their ethnic, place-specific congregations and evangelistic networks on such a grand scale and with such high visibility across Europe, thanks to the practical logic of Christian entrepreneurs and the dynamic, locally developed business model of Wenzhou church development (Cao 2008). They are known as China's global go-getters, spreading Chinese commerce across the globe. In particular, they operate small businesses such as garment factories and trade light industrial products between China and Europe and across Europe. They have brought an indigenous Chinese Christianity to Europe along with their household based economy. Popularly known as "China's Jerusalem", the coastal Chinese city of Wenzhou is home to thousands of self-started home-grown Protestant churches and a million Protestants (around 20\% of the local population), and has become a regional center of global capitalism since the 1990s (Cao 2011).

Most Chinese churches in Europe are not officially registered as religious organizations but as nonprofit organizations due to various legal restrictions in the host society. ${ }^{6}$ Some do not register at all for the purpose of avoiding official scrutiny or just for convenience. Furthermore, most of them have actively avoided contact with non-Chinese local churches or congregations in Europe. The formation and expansion of this diasporic religious community relies heavily on these Wenzhou traders' newfound wealth from transnational business and the informal household based model of church development. This can be seen as a natural extension of the extensive house church networks operating in legal gray areas in mainland China. Wenzhou churches in Europe are usually controlled and managed by a small number of nondenominational male lay leaders or "boss Christians" who financially contributed the most to purchasing or acquiring the church properties (cf. Cao 2008). The churches also serve as a nexus of social power for them. Not unlike rural house churches in China, the household economy constitutes the backbone of church development in the Chinese diaspora, and accordingly migrant churches always refer to the number of households (hu 户) as the basic unit rather than the number of baptized individuals when calculating membership size. Chinese migrant church leaders encourage the practice of endogamy among church members both as a way to achieve, and as a byproduct of, congregational stability, and the ethnic community, the congregation, and individual households form many concentric circles with God being at the center. This tight-knit community and family atmosphere is especially salient among Wenzhou Chinese immigrants in France. Wenzhou Christians in France enjoy a relatively long history with some geographic advantage in conducting business and religious activities, which tend to develop around Paris-the international trade metropolis.

One Paris-based Wenzhou preacher and garment trader says that if his business fails he can still rely on the 180 households in his church, and the brothers and sisters would not let him starve. Migrant church leaders are not only socioeconomically connected to their congregations within France but also maintain transnational ties with those who lead migrant Wenzhou churches in other European nations and whom they had prior contact back in the Wenzhou church in China before their emigration. This has resulted in transnationally coordinated efforts to fund new Chinese church building projects

5 There are also Wenzhou Christian merchants in North America, but they do not form their own place-based business enclave or congregations, partly due to their small population and their spatial dispersion. Chinese immigrants from Fujian and Guangdong have traditionally dominated Chinatowns and Chinese Christian churches in North America whereas Wenzhou immigrants are latecomers.

6 Specifically, in France Chinese churches tend to be registered as "Association" in accordance with the French association law of 1901, and in Italy as "Organizzazione Non Lucrativa di Utilità Sociale" (ONLUS). 
both in China and in Europe and to launch high-profile joint petitions against the recent Chinese state-led cross-removal campaign that removed hundreds of rooftop crosses in Wenzhou and the surrounding regions in Zhejiang Province. ${ }^{7}$ Church workers and lay leaders often further expand their networks throughout the European Union as their family businesses move from one country to another, seeking new opportunities and taking advantage of the visa-free regime in the Schengen zone. Accordingly, there is a preacher rotation system (paigong 派工) following the Wenzhou model of church development, through which preachers regularly rotate among migrant churches within the host country and sometimes even across different Schengen countries. Both in conducting church work and doing business, they take Europe as a whole.

Wenzhou Chinese churches in France might be a unique case. Against the backdrop of China's current globalization; however, their strategy of adaptation is not uncommon. The growth of Chinese Christianity in Italy proceeds in a similar fashion but in an institutionally distinct way as in France. Comparing to the tight-knit ethnic religious enclave centering in Paris, Chinese migrant churches in Italy spread all over its long, narrow, strip-shaped territory in geographically dispersed settings and are mainly organized into three distinct but interconnected parishes (muqu 牧区), namely the northern parish, the middle parish and the southern parish. ${ }^{8}$ All of the three parishes operate under the national central board of deacons (zonghui zhishihui 总会执事会). In both countries, Chinese merchant families play an essential supportive role behind the expansion of immigrant Chinese Christian church. In particular, Wenzhou Chinese merchants, traditionally with a strong cultural emphasis on familialism, dominate the leadership structure of the immigrant churches. Developing in two different countries in parallel, Chinese migrant Christian communities share the same family model of operation, characterized by congregational independence, an autonomous space, and a conservative patriarchal morality, while adapting to different local contexts.

Among countries in the European Union, Italy's lax immigration control and less developed commercial economy are external factors behind why Italy-based Chinese Christians tend to have higher mobility and develop even stronger internal religious bonding. After the economic crisis in the Euro-zone, Italian industries suffered from heavy damages. Many enterprises and businesses went bankrupt and were closed down. The crisis has led to many Chinese Christian businesspeople migrating out of the surrounding parishes that they used to live. It is also not uncommon for them to relocate during seasonal downtime. The spatial dispersion of more than fifty major Chinese immigrant churches throughout the Italian territory allows these mobile traders and merchants to find their new churches or meeting points nearby relatively easily wherever they travel. ${ }^{9}$ This unique religious spatial arrangement, together with a centralized nationwide preacher rotation and dispatch system, also encourages mobile religious agents such as lay leaders and preachers to move from one place to another without losing their social and religious capital within the larger ethnic religious system. Their credentials and leadership positions are recognized not only throughout the national system of Chinese church coworkers in Italy, but also in neighboring Greece and Malta, where there are newly planted Chinese migrant churches.

Unlike their counterparts in Italy who scatter around the country and are governed by a centralized national pastoral system, most Chinese immigrants in France have chosen to live in Paris due to the availability of vast business opportunities there. Furthermore, many Chinese Christians in Paris I have

7 For details of the church cross-removal campaign (see Cao 2017).

8 This parish system is clearly borrowed from the Wenzhou model of church development in China. Unlike in Wenzhou where each parish is responsible for dispatching preachers to different churches to conduct services, in Italy it is the national central board of deacons that is in charge of the entire preacher-dispatch system among the immigrant Chinese Christian community and coordinates church work between different parishes. In France, Chinese churches tend to concentrate in Paris and there is thus no need to adopt this parish system.

9 In Italy, besides a major unified evangelical Chinese Church system that consists of more than fifty churches and more than two hundred centrally appointed preachers across the nation, there is a much smaller, separately organized Pentecostal and charismatic-oriented Chinese church system called the Chinese revival church (huaren fuxing jiaohui). 
come to know have arrived in France from Italy, seeking business opportunities. For them, Italy is more suitable as a transfer station while France is the true final destination. Due to the dominance of socioeconomically advantaged elite and elderly overseas Chinese immigrants, the immigrant Chinese churches in Paris have developed in a highly competitive context with each protecting its relative organizational independence and guarding against the act of "stealing sheep" by other churches. The oldest Parisian Wenzhou Chinese church that claims more than a thousand registered members has recently split into several smaller churches because of unresolved internal conflicts among elderly lay leaders. Nevertheless, Chinese immigrant churches in Europe are, after all, not elite Chinese organizations overseas like the chamber of commerce, but constitute a large, openly participatory domain and a popular grassroots movement of new immigrants. The nationwide system of Chinese Christian parishes which spread all over Italy acts as a good example. It has not only met the need of mass social participation by nonelite immigrants who are often on the move for new business opportunities and who are relatively socioeconomically homogenous, but made it possible to mobilize material and pastoral resources readily across regions for the launch of new church programs and the staging of major evangelistic events.

Under this centralized pastoral system, more than two hundred lay preachers have been chosen to affiliate with the national board of coworkers (zonghui tonggong 总会同工), and each Sunday they are dispatched to different Chinese churches across Italy to deliver sermons. This number is still growing as more Chinese churches are being planted in Italy and need immediate pastoral resources and service. One young preacher belonging to this national system of co-workers told me that all of the preachers within this system work as part-time volunteers and do not receive remuneration or reimbursement of travel expenses in any form because they consider their work as an act of self-sacrifice and spiritually meaningful. This means they have to use personal funds to cover their substantial travel expenses. As a result, only well-to-do merchants or traders can afford to take this mobile job.

The development of Chinese immigrant churches in Europe has been subjected to normative "isomorphic pressures" (DiMaggio and Powell 1983). When immigrant Chinese merchants, consciously or unconsciously, bring and integrate a relatively successful business model and pragmatic business logic into their church organizations, the operation of the latter would resemble that of an immigrant business enterprise. Wenzhou merchants' family businesses and their immigrant churches are isomorphic in operational logic and organizational structure. In particular, immigrant church leadership tends to lie in the hands of close relatives as in the case of immigrant family firms. This institutional isomorphism is further reflected in their practices of investment, endogamy, and the construction of family relationship, all of which is conducted in a similar fashion with achieving family solidarity and fulfilling communal commitment as the ultimate goal and fundamental value. The immigrant family and the family-style church provide the perfect emotionally supportive context for the transmission of the religion cross generationally. Chinese youth spend much time socializing with one another in various church settings such as youth fellowship meetings, bible study groups, youth group outings, summer and winter camps, Christmas performance, and evangelization-related activities, and consequently they tend to meet their potential mates in a highly controlled Chinese context. Sometimes the training of the younger generation of preachers and church leaders also starts from the immigrant family-style church. Young would-be preachers are usually arranged to first practice preaching in front of an audience that includes their parents and grandparents or in front of their home churches attended by relatives before being formally considered and appointed by the national board of deacons of the immigrant Chinese church.

This institutional isomorphism can also find expression in the use of church space. One direct example is the story of a Wenzhou church lay leader and garment businessman in Paris who uses the site of the local church as his business office. When he was asked about why his office address on his business card is the same as that of the church, he frankly responded "when activities are held in the church, this is the office for the church, otherwise it is the office for my business." The line between the church and the secular business world is rather casual and ambiguous, which to some 
extent reflects the pragmatic business logic of immigrant lay leaders. The church's nonregistered status also allows lay leaders to merge business with religion without legal hurdles. This partly explains why many of the Chinese immigrant churches are not formally registered as religious sites. Without an overarching central interpretive authority structure in managing religious practices and symbols, immigrant churches are prone to becoming a multifunctional community center that caters to the socioeconomic needs of the immigrants who, instead of taking cultural assimilation for granted, value social, material, and spiritual connections with the Chinese homeland. This highly mobile household-based Chinese Christianity, with its emphasis on transnational religious connections and institutional and spatial autonomy in diaspora, provides an important counterpoint against the popular views on Christian conversion and cultural assimilation that characterize the research paradigm of US-based immigrant religions (see Warner 1993).

\section{The Discourse of a Globalizing Chinese Christianity and the Salience of State Categories in Global Evangelization}

In recent years, backed by China's intensified commercial engagement with Europe, there has been a shift of direction in today's Chinese mission movement, from a Western mission-founded into-China movement focusing on work among Chinese minorities to an ethnic Chinese-led global mission movement. This has much to do with the worldly engagements of diasporic Chinese Christians in Europe who are spearheading this movement and who seek to integrate their evangelical work with the Chinese state-led "one belt, one road" initiative for global development. These Chinese Christian lay leaders have intentionally developed connections with hegemonic state discourse on cultural nationalism as embodied in the Chinese dream of national rejuvenation. In so doing, they flexibly position themselves as a contributing force in the current Chinese project of nation building and global reordering (rather than forces of global western cultural imperialism). It is noteworthy that unlike what Western missionaries in China did a century ago, today's Chinese Christians in Europe are not evangelizing Europeans, but forming exclusive congregations, although there is a popular discourse in the church highlighting the role of the diaspora Chinese in an envisioned "reverse mission" to Europe. There are tight national and ethnic boundaries undergirding this Chinese "mission" which mainly targets fellow Chinese immigrants at the current stage.

Europe needs spiritual revival (lingming fuxing 灵命复兴), and Chinese churches can work together to bring God's blessings to Europe. This is a recurring theme repeatedly popped up in the sermons and church-run seminary training courses in migrant Chinese churches. The regular and frequent face-to-face gathering of mobile migrant Chinese church leaders from different parts of Europe, facilitated by the visa-free scheme of the Schengen region, further strengthens such a Chinese-centered vision among the first generation of immigrants. While they acknowledge a debt to Europeans for bring Christianity China a century ago, they now assume the responsibility of global evangelization. In contrast to France where French republicanism stresses cultural assimilation and where laïcité has been a dominant ideological principle of secularism in society, Italy is far more tolerant to the public presence of immigrant religions, and a lot of immigrant Chinese Christian evangelistic projects and outreach activities have taken place in Italy. For example, sponsored by the "one belt, one road" gospel network, the first Sino-Europe evangelism symposium (hua'ou xuanjiao yantao dahui 华欧宣教研讨大会) was held in Rome in September 2017 with the theme "Challenges and Mission of the Chinese Church in Europe in the 21st Century". Topics discussed include the Islamization of Europe, refugee crisis, homosexual marriage, youth problems, and the Chinese evangelical mission in Europe. In October 2018, a pan-Europe pastoral ministry and leadership symposium (quanou jiaomu ji jiaohui lingxiu yantaohui 全欧教牧暨教会领袖研讨会) with the theme “calling and mission" (huzhao yu shiming 呼 召与使命) was held in Rome and attended by nearly 200 people. Church leaders from 12 European nations were invited to share information about the Chinese churches in their respective nations and consolidate the Chinese evangelistic vision. 
Facilitated by the discourse on globalizing Chinese Christianity, some high profile evangelical events have taken place in Italy. Under the larger context of religious and cultural pluralism in Italy, Chinese immigrant churches have successfully staged several public special gatherings (tehui 特会) that brought together young Chinese from different parts of Europe. At such occasions, Christian-filtered Chinese cultural values are celebrated and inscribed in European public space, where issues of cohabitation, homosexuality, and abortion are increasingly tolerated. Evangelical Christianity offers these Chinese migrants a new lens in which to interpret their migrant experience and identity as well as articulate a spiritual defense against cultural assimilation into European secularity and social liberalism.

The most important and memorable activity I participated in during my field trip to Europe was “Love in Rome Century Music Festival” (ai zai luoma 爱在罗马) on June 30, 2018. The Chinese evangelical music event in the heart of the Eternal City was the first major European public event for evangelical Chinese Christians with the aim to celebrate the Apostles Peter and Paul 1950 years after their martyrdom. Officials from the municipal government of Rome were invited to attend to lend legitimacy to this Chinese cultural event and the Vatican newspaper La Stampa featured a long report titled "Chinese evangelical Christians in Rome, in memory of the martyrs" in its world news section afterwards. The choice of the location-the Circus Maximus-where Christians were said to be persecuted by the emperor Nero in ancient Rome, burn alive or eaten by wild beasts, was a deliberate attempt to symbolically mark the change in the spatial structure of global Christianity and highlight the spiritual role of the Chinese. The event featuring several Chinese Christian pop music stars drew several thousand young evangelical and Pentecostal Chinese Christians not only from Rome and from all over Italy, but also from other European countries who arrived on coaches. ${ }^{10}$ The resources and funds for producing this public event mostly came from the Wenzhou church in mainland China. The total cost for this 3-hour concert was 6 million yuan (about 800,000 USD). ${ }^{11}$ Preachers from Wenzhou, China were invited to give sermons and prayers in Rome in Mandarin Chinese and to help convert new Chinese immigrants. The concert opened with a short documentary introducing the history of Chinese migration from Wenzhou to Europe, putting the evangelical Christian event in the reform-era context of China's economic globalization. This shift in the direction of the new mission movement is not only reflected in the spatial movement of pastors and lay preachers but also seen in the movement of religious objects. Bibles, hymn books, and even choir robes used in the Chinese churches in Europe are almost all imported from China.

The main idea that has emerged from my close encounters and interactions with these migrant Chinese Christians and enables me to think Chinese Christianity differently is that the usual nation-state centered framework of church-state relations might not be adequate in capturing the dynamism and vitality of Chinese Christianity at this contemporary global moment. As China's official restrictions on religion increasingly motivate the Chinese house church to channel its resources to a "reverse mission" overseas, a group of transnational Chinese Christians have actively engaged in producing religious activities and events that link China and Europe and in attaching evangelistic meanings and symbolic markings to Europe's urban space. For instance, the Mission Center (xuanjiao zhongxin 宣 教中心) of the Chinese Christian Church in Italy used to be mainly responsible for organizing and supporting short-term mission trips each summer to the interior, western regions of China, often in collaboration with the Wenzhou church in China. It has shifted its priority in operation since the Chinese government stepped up measures against Christian missionary activities and their mission stations in ethnic southwestern China, to which they had regularly conducted evangelization from

10 According to my count, there were approximately 3000 to 4000 attendees at this event. Some evangelistic Chinese church leaders put the event attendance number at 20,000, which is a gross exaggeration apparently out of a desire to put them at the center of a great revival.

11 Although there are strict financial regulations in Europe, money can easily flow between China and Europe in both directions through informal channels. Sometimes, Chinese immigrants can even complete their business transactions in Europe by simply mobilizing and transferring funds between their bank accounts within China. 
Europe, were closed down. Targeting the unreached potential converts in Europe, especially the Chinese immigrant youth and second generation youth at the current stage, these well connected and globally positioned lay leaders and preachers quickly redirected their resources and energies back to Europe.

In the same line of using Europe as a base for Chinese evangelism, a Chinese Christian preacher couple who attend the same migrant church has set up a tourist company that caters to the need of Chinese Christian customers from both Europe and China who come to Rome to visit the footsteps of the apostles in the bible in order to deepen their spirituality. The Christian wife acts as tour guide and Italian-Chinese interpreter. They are proud of their ability to tease out and narrate the spiritual significance of the European city based on solid biblical knowledge in guided tours. Besides operating regular tours for tourists from China, the Christian tour company has been most frequently used by members of Europe-based Chinese churches and visiting Chinese pastors and preachers from other parts of the world. Sometimes they offer discounted service to those who can bring along potential Chinese converts, thus creating an ethnic religious and commercial node within the larger structure of the enclave economy. They also organize frequent group pilgrimage trips to Jerusalem for Chinese guests in Europe and those directly from China. Near China's public holidays such as the golden week for the National Day, their online advertisement would urge Chinese Christians in Europe to invite their relatives back in China to visit Europe's historical Christian sites, by making euro payments in Europe for the tour services.

The strong emphasis on the central role of the Chinese race in the evangelistic vision of bringing Christian blessings to Europe seems unequivocally ethnocentric. It nevertheless speaks to the reality of China's rising soft power on the global stage associated with its economic rise that has culturally empowered Chinese migrant traders and merchants in general. It comes no surprise that Chinese Christian groups choose to emphasize ethnic or subethnic identity as a deliberate evangelistic strategy in a historically and traditionally Christian cultural context (cf. Nyíri 2003). This also seems to be a common pattern among Asian American Christians (Yang and Ebaugh 2001). However, the main difference between Chinese Christians in Europe and their counterparts in America is the former's strong cultural entwinement with Chinese state categories and its being a salient marker of communal identity. This echoes what I have depicted in a previous study on the phenomenon of "spiritual nationalism" in the reform-era Chinese Christian context. I use the term to capture the multilayered process in which advantaged urban Chinese Christians internalize nation state norms, fashion themselves as modern religious subjects compatible with the nation-building project, and adapt and contribute to the rise of nationalism from below (Cao 2012). Some Chinese Christian groups have formulated what they call “God's China vision" (zhongguo yixiang 中国异象), meaning that China will rise not only in the economic sphere but also in the spiritual realm. As one Wenzhou Christian businessman put it, characteristically, "The international community is paying great attention to China. To look at the GDP, China is now the second largest economy. In the spiritual field China may take the last baton in the global evangelical movement."

The competing and even militant global religious vision can be found in the Chinese-led "Back to Jerusalem Movement". The ultimate goal of the China vision is for the Chinese to evangelize the Muslim nations in the Middle East and eventually bring the Gospel back to Jerusalem. Although the "Back to Jerusalem Movement" has incurred criticism from some Western-based China ministries for being a scam, today, in the Chinese immigrant church circle, many believe that the Gospel came from Jerusalem and it must be brought back to Jerusalem eventually. In their narratives, this is like running a relay race in which different countries and peoples in different periods play different roles in this great mission of evangelizing the globe. It is not exaggerating to say that a transnational geography of Chinese Christianity has emerged with the Chinese diaspora in Europe being the center of God's mission. However, the discourse about Chinese as the main vehicle for bringing the gospel to Europe is kept very general and almost always with reference to the expected role of second generation Chinese immigrants in reaching out to potential (non-Chinese) European converts. This attests to the fact that 
there is currently a general lack of inter-ethnic exchanges and trust among the first generation in the Chinese churches in Europe.

In secularized Europe, evangelical Christianity can provide a normative and morally superior context for migrant Chinese to imagine their native place and a shared future of their cultural positioning in an increasingly exclusionary context (Cao 2013a). In France, more than in Italy, Chinese immigrant churches have developed in the direction of high tension with the secular culture of the host society, creating a parallel society and an enclave of identities, faith, and businesses. To fend off unwelcome secular cultural influence from the mainstream society, some indigenous Chinese preachers have used a conservative religious language associated with moral absolutism to train young church members and church workers. In so doing, these immigrant churches are able to effectively pass on their evangelical faith to the younger generation in a spiritual and moral enclave.

This Sinocentric project of global evangelization involves a redemptive process in which advantaged Chinese Christians seek to overcome victimization and suffering inflicted by secular state modernity through repaying China's “gospel debts" (fuyin zhai 福音债) to missionary-sending Western nations a century ago. Backed by their recent experiences and memories of state-led spectacular economic modernization and shaped by the values of their social class, urban elite male Christians often show willingness to embrace state categories and express contempt for the lack of textual theological knowledge and greater social concerns among lay women and elderly members (Cao 2013b). Inspired by nationalistic native Pentecostal leaders in the early twentieth century, their prophetic vision is that China will eventually rule the world not only in economic terms, but also in the spiritual realm, and China will transform from a traditional missionary receiving nation to a glorious missionary sending nation.

\section{Conclusions: Thinking beyond the Static Category of World Religions}

With the rise of a powerful international discourse on nation-building, the type of religiously inspired self-imposed moral isolation among Chinese Christians in diaspora as described above might continue to heighten. While this sinicized version of Christianity offers an alternative to the secular Chinese project of nation building by addressing the "China dream" in spiritual terms, it seems unlikely to contribute to the building of a global civil society with an insular island mentality. This socioreligious phenomenon begs the following questions. Is this a case of malfunction of the world religion or just an example of uncivil local communal religion? Can a "sinicized" world religion possibly avoid entanglement with state power and ideology in the context of China's modernization and globalization?

In the book Flourishing: Why we need religion in a globalized world Protestant theologian Miroslav Volf (2016) provides us with a theologically-framed global religious vision in which great world religions such as Christianity and Islam can play a positive role in achieving peace and reconciliation and in establishing a global order. This normative theological argument provides the public with a unique religious perspective on the ongoing and morally ambivalent project of globalization which has often been habitually understood in political economic terms. It sheds light on how religionists should coexist and deal with nonreligious or a-religious people. However, its definition of world religions (p. 69), which is centered on "transcendence" and its distinction from the local mundane realms of culture, politics and the economy, is typically a theological construct that guides human interaction but not about religion as experienced in real-life setting. Such normative theological definition clearly puts world religions and local religions in a static, overessentialized, dichotomous framework. Volf $(2016$, p. 86) goes so far as to argue that "local religions with universal pretensions are the most violent of all religions." If we can break from traditional congregational studies of Christian churches and overcome congregational barriers in looking at Chinese Christianity and its relationship with identity formation, community development and everyday life in the Chinese diaspora, we will soon be able to come to the conclusion that the great world religion of Christianity has been adopted and made very local by those practicing it in daily context. Indeed, empirically speaking, all religions 
bear universalist tendency and locally embedded features, although there are important tensions between the universalizing aspects of religion to which migrant populations may appeal, and their specific localized forms which provide a sense of stability and identity in an otherwise rootless world (Tapp 2014).

This study advances the research on immigrant religious organizations, which has been to a large extent modeled on the American experience. It goes without saying that the history of human migration long preceded the emergence of nation states. In the past two centuries of globalization, migration and the rise of an international system of nation states have developed symbiotically, and migration control has gradually become a sovereign right of receiving nations (McKeown 2008). In the earlier phase of globalization, lack of Christianity constituted part of a moral argument to justify the U.S. exclusion of Chinese labor immigrants and strict border control in the 1880s, while the other side of the coin is that for centuries Christian missionaries have traditionally travelled in a north-to-south direction. However, today's diasporic Chinese church networks have spread horizontally across the Schengen region and created diaspora mission stations in the global North. The increasingly coordinated development of a sinicized Christianity in Europe has spiritualized private Chinese business and familial interests, and Europe is even presented as an important battleground of the global evangelization of the gospel by the Chinese. As such, Christianity is far from a passive, responding force at the contemporary stage of China's global business outreach and mass Chinese emigration. This highly mobile, sinicized version of Christianity, imbued with intense worldly aspirations, requires us to transcend the traditional Western-centric view of Chinese Christianity as simply a derivative of Western missionary Christianity and to closely examine the cultural identity and moral imagination of Chinese Christians in agentive pursuit of prosperity and success at this contemporary global moment.

Funding: This work was supported by a grant from the fund for building world-class universities (religious studies) of Renmin University of China (project no. 2018).

Acknowledgments: I thank Roberto Cipriani for giving me the opportunity to stay at the International Center for the Sociology of Religion during the summer and winter of 2018 while I was conducting fieldwork in Rome.

Conflicts of Interest: The author declares no conflict of interest.

\section{References}

Asad, Talal. 1993. Genealogies of Religion. Baltimore: The Johns Hopkins University Press.

Berger, Peter, Grace Davie, and Effie Fokas. 2008. Religious America, Secular Europe?: A Theme and Variations. London and New York: Routledge.

Cao, Nanlai. 2005. The Church as a Surrogate Family for Working Class Immigrant Chinese Youth: An Ethnography of Segmented Assimilation. Sociology of Religion 66: 183-200. [CrossRef]

Cao, Nanlai. 2008. Boss Christians: The Business of Religion in the "Wenzhou Model" of Christian Revival. The China Journal 59: 63-87. [CrossRef]

Cao, Nanlai. 2011. Constructing China's Jerusalem: Christians, Power, and Place in Contemporary Wenzhou. Stanford: Stanford University Press.

Cao, Nanlai. 2012. Elite Christianity and Spiritual Nationalism. Chinese Sociological Review 9: 27-47. [CrossRef]

Cao, Nanlai. 2013a. Renegotiating Locality and Morality in a Chinese Religious Diaspora: Wenzhou Christian Merchants in Paris, France. The Asia Pacific Journal of Anthropology 14: 85-101. [CrossRef]

Cao, Nanlai. 2013b. Gender, Modernity, and Pentecostal Christianity in China. In Global Pentecostalism in the 21st Century. Edited by Robert Hefner. Bloomington: Indiana University Press, pp. 149-75.

Cao, Nanlai. 2017. Spatial Modernity, Party Building, and Local Governance: Putting the Christian Cross-Removal Campaign in Context. China Review 17: 29-52.

Cao, Nanlai. 2018. A Review of Globalization and the Making of Religious Modernity in China. The China Journal 80: 169-72. [CrossRef]

Cao, Nanlai, Giuseppe Giordan, and Enzo Pace, eds. 2018. Chinese Religions in China and Italy. Religioni e Società 91. [CrossRef] 
Casanova, Jose. 2018. Locating Religion and Secularity in East Asia Through Global Processes: Early Modern Jesuit Religious Encounters. Religions 9: 349. [CrossRef]

Cayton, Horace R., and Anne O. Lively. 1955. The Chinese in the United States and the Chinese Christian Church. New York: Bureau of Research and Survey, National Council of the Churches of Christ in the United States.

Chan, Sucheng. 1991. The Exclusion of Chinese Women, 1870-1943. In Entry Denied: Exclusion and (the Chinese Community in America 1882) the Chinese Community in America, 1882-1943. Edited by Sucheng Chan. Philadelphia: Temple University Press, pp. 94-146.

DeBernardi, Jean. 2001. The Localization of Christianity among Chinese in Singapore and Malaysia. In Chinese Populations in Contemporary Southeast Asian Societies: Regional Interdependence and International Influence. Edited by Jocelyn Armstrong, Warwick Armstrong and Kent Mulliner. London: Curzon, pp. 171-208.

DiMaggio, Paul, and Walter W. Powell. 1983. The Iron Cage Revisited: Institutional Isomorphism and Collective Rationality in Organizational Fields. American Sociological Review 48: 147-60. [CrossRef]

Goossaert, Vincent, and David Palmer. 2011. The Religious Question in Modern China. Chicago: University of Chicago Press.

Jansen, Thomas, Thoralf Klein, and Christian Meyer, eds. 2014. Globalization and the Making of Religious Modernity in China: Transnational Religions, Local Agents, and the Study of Religion, 1800-Present. Leiden and Boston: Brill.

Li, Minghuan. 1999. “To Get Rich Quickly in Europe!”: Reflections on Migration Motivation in Europe. In Internal and International Migration: Chinese Perspectives. Edited by Frank N. Pieke and Hein Mallee. Richmond: Curzon, pp. 181-98.

McKeown, Adam. 2008. Melancholy Order: Asian Migration and the Globalization of Borders. New York: Columbia University Press.

Nagata, Judith. 2005. Christianity among Transnational Chinese: Religious Versus (Sub)ethnic Affiliation. International Migration 43: 99-130. [CrossRef]

Nyíri, Pál. 2003. Moving Targets: Chinese Christian Proselytising among Transnational Migrants from the People's Republic of China. European Journal of East Asian Studies 2: 263301. [CrossRef]

Tapp, Nicholas. 2014. Epilogue: Religion and Mobility in a Globalising Asia. In Religion and Mobility in a Globalising Asia: New Ethnographic Explorations. Edited by Sin Wen Lau and Nanlai Cao. London and New York: Routledge, pp. 119-28.

van der Veer, Peter. 2013. The Modern Spirit of Asia: The Spiritual and the Secular in China and India. Princeton: Princeton University Press.

Volf, Miroslav. 2016. Flourishing: Why We Need Religion in a Globalized World. New Haven: Yale University Press. Warner, R. Stephen. 1993. Work in Progress toward a New Paradigm for the Sociological Study of Religion in the United States. American Journal of Sociology 98: 1044-93. [CrossRef]

Yang, Fenggang. 1999. Chinese Christians in America: Conversion, Assimilation, and Adhesive Identities. University Park: Penn State University Press.

Yang, Fenggang, and Helen Rose Ebaugh. 2001. Religion and Ethnicity among New Immigrants: The Impact of Majority/Minority Status in Home and Host Countries. Journal for the Scientific Study of Religion 40: 367-78. [CrossRef]

Yang, Fenggang, and Joseph Tamney. 2006. Exploring Mass Conversion to Christianity among the Chinese: An Introduction. Sociology of Religion: A Quarterly Revieww 67: 125-29. [CrossRef]

(C) 2019 by the author. Licensee MDPI, Basel, Switzerland. This article is an open access article distributed under the terms and conditions of the Creative Commons Attribution (CC BY) license (http://creativecommons.org/licenses/by/4.0/). 